\title{
A New Tool to Assess Groundwater Resources in the Mississippi Embayment
}

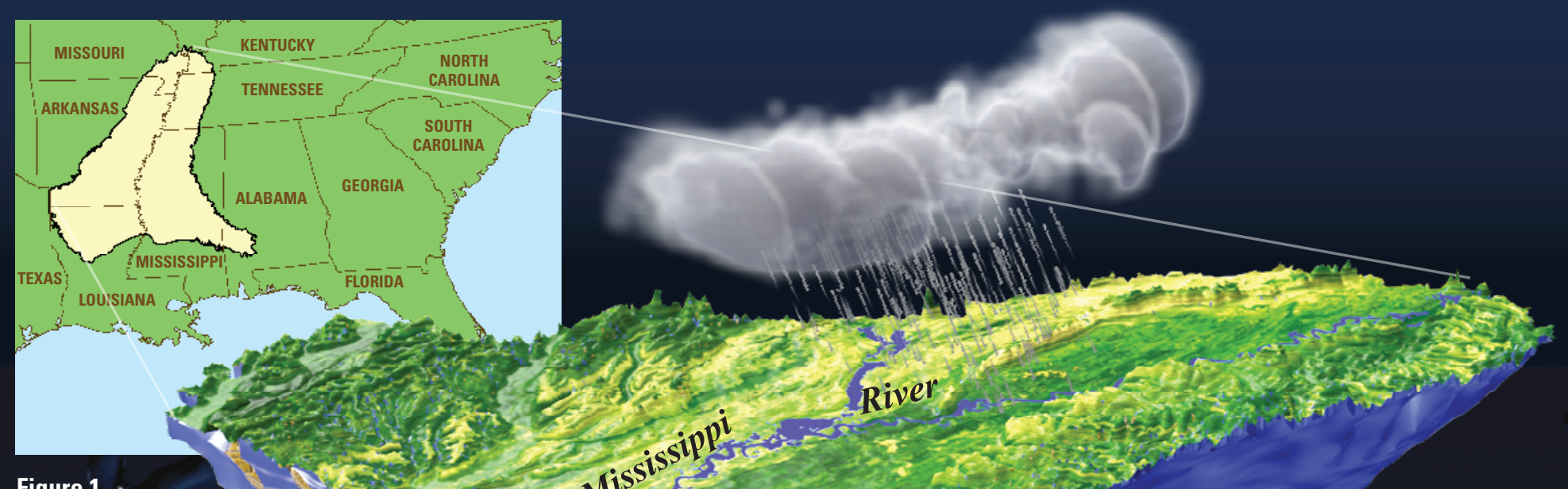

Figure 1.

Location and stylized threedimensional view of the Mississippi embayment study area.

\section{What is the Mississippi Embayment?}

The Mississippi embayment study afea encompasses approximately 78,000 square miles in eight States and includes large parts of Arkansas, Louisiana, Mississippi, and Tennessee, and smaller areas of Alabama, Illinois, Kentucky, and Missouri (fig. 1). The Mississippi embayment is essentially a basin that slopes toward the Gulf of Mexico and is filled with sediments of alternating sand, silt, and clay layers. There are two principal aquifers in the embayment- the Mississippi River Valley alluvial aquifer (alluvial aquifer) and the middle Claiborne aquifer (fig. 1). The shallow alluvial aquifer is the primary source of'groundwater for irriga-

tion in the largely agricultural region, while the deeper middle Claiborne aquifer is a primary source of drinking water for many of the 5.2 million people living in the embayment.

The U.S. Geological Survey (USGS) is conducting large-scale multidisciplinary regional studies of groundwater availability for the Nation. Studies comprise individual assessments of regional groundwater-flow systems that encompass varied terrains*and document a comprehensive regional and national perspective of groundwater resources. Collectively, these studies are the foundation for the national assessment of groundwater availability and are conducted in cooperation with other Federal, State, local governments, and the private sector. Numerical groundwater-flow models are used in these studies to document effects of human activities and climate variability on groundwater levels, changes in aquifer storage, and flow between groundwater and surface-water bodies.

As part of the Mississippi Embayment Regional Aquifer Study (MERAS), a numerical model was constructed of 13 layers over $78_{3}, 000$ square miles representing multiple aquifers and confining units for the period of 1870 to 2007 . The model is a tool that was used to assess and better understand groundwater resources. 
An estimate of the volume of water stored in the alluvial aquifer was made by calculating the simulated thickness of the saturated zone and multiplying by the specific yield. The volume of water in 2007 stored in the alluvial aquifer was estimated to be approximately 536 million acre-feet (equivalent to 10.7 feet of water covering the entire study area). Cumulative storage change within all the aquifers simulated in the MERAS model indicates overall depletion of 140 million acre-feet (equivalent to 2.8 feet of water covering the entire study area, and most of the water is from the alluvial aquifer) from 1870

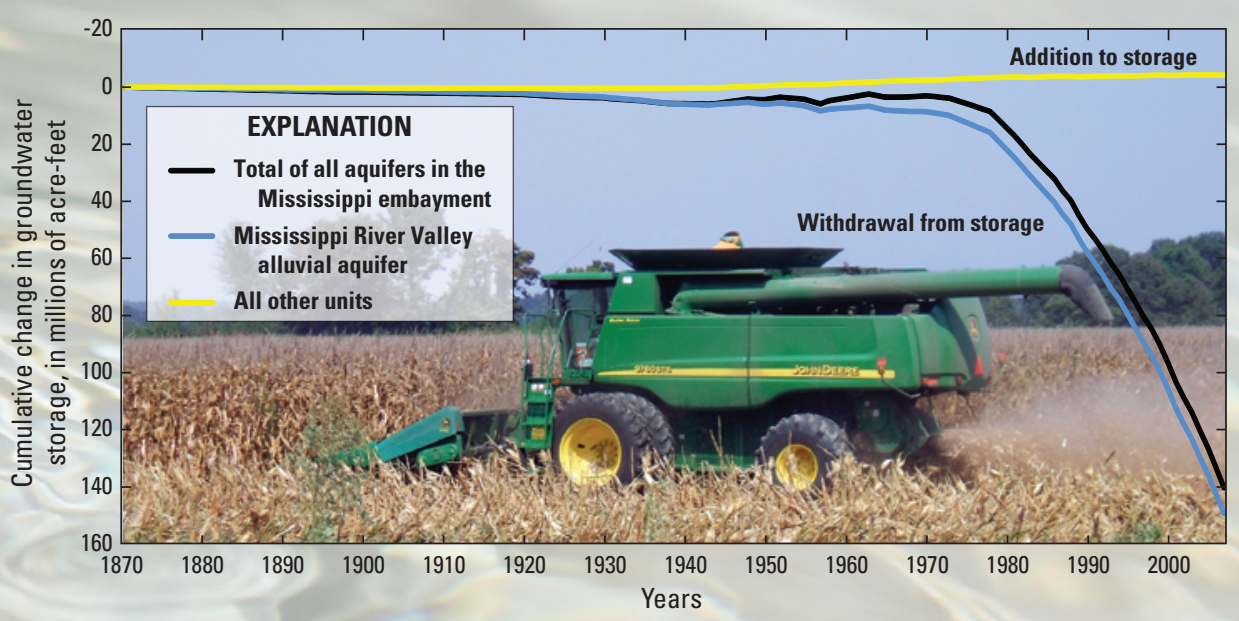

Figure 2. Cumulative change in groundwater storage by aquifer. The total change for all aquifers is less than the alluvial aquifer because of addition to storage from other units.

(fig. 2). Therefore, the total amount of water removed from aquifer storage to date in the Mississippi embayment equals approximately 26 percent of the amount stored only in the alluvial aquifer.

Specific yield-The ratio of the volume of water that will drain under the influence of gravity to the volume of saturated rock.

\section{How much and where is groundwater being used?}

An estimated 12 million acre-feet per year (11 billion gallons per day) of groundwater was pumped in 2005 from aquifers in the Mississippi embayment. Irrigation constitutes the largest groundwater use, accounting for approximately 11 million acre-feet per year (10 billion gallons per day) in 2005 from the alluvial aquifer in Arkansas, Louisiana, Mississippi, and Missouri, and to a lesser extent in Illinois, Kentucky, and Tennessee.

Cumulative groundwater pumpage from 1870 through 2007 from the alluvial aquifer amounts to over 280 million acre-feet (enough to cover the entire study area with more than 5 feet of water) or approximately 87 percent of the total cumulative amount pumped (fig. 3). Cumulative pumping is greater than the cumulative change in storage because some of the demand for pumping is offset by recharge or inflow through streambeds. The amount pumped from the alluvial aquifer

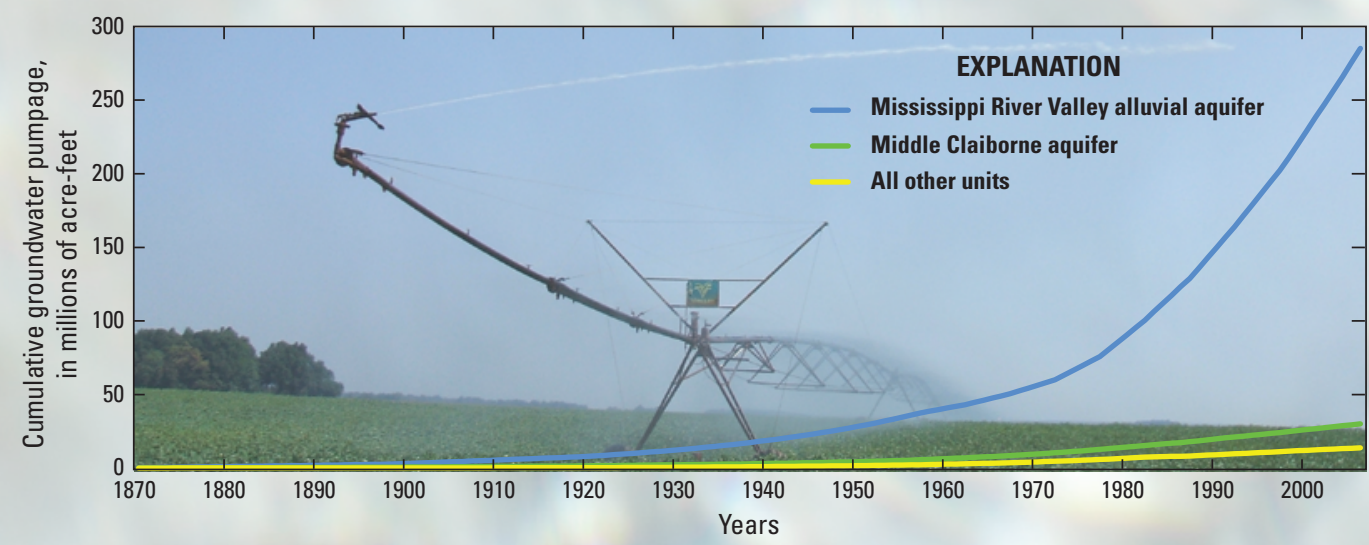

Figure 3. Cumulative groundwater pumpage in the Mississippi embayment. is more than nine times that from the middle Claiborne aquifer, which is the second largest producer of groundwater in the Mississippi embayment. Cumulative groundwater pumped from the middle Claiborne aquifer made up approximately 9 percent of the total, while combined pumping from remaining aquifers made up 4 percent.
Groundwater availability - Groundwater availability comprises many factors. These factors include water law, regulations, economics, infrastructure, quality of water, and quantity of water. The focus of the USGS MERAS is to examine the quantity factor or the amount of groundwater available in the Mississippi embayment. The quantity of groundwater in the embayment is changing because of natural and anthropogenic events such as precipitation, land use, stream channelization, and pumping. 


\section{What has been the effect of groundwater pumping?}

Water-level declines have occurred across large areas in the Mississippi embayment because of groundwater pumping. Water-level declines in the alluvial aquifer are noticeable throughout Arkansas and parts of Mississippi. Model simulations indicate 216 square miles (about 0.7 percent of the study area) of declines of more than 100 feet in the alluvial aquifer by 2007 (fig. 4). Waterlevel declines in the middle Claiborne aquifer are more dramatic with 7,529 square miles (13.3 percent) showing water-level declines of more than 100 feet by 2007 . The largest declines of more than 300 feet in water-level declines in the middle Claiborne aquifer occur in southern Arkansas and northern Louisiana.

Water-level declines are much greater in the middle Claiborne aquifer because it is under confined conditions, unlike the alluvial aquifer. Small changes in pumping from the middle Claiborne aquifer result in large changes in water level.

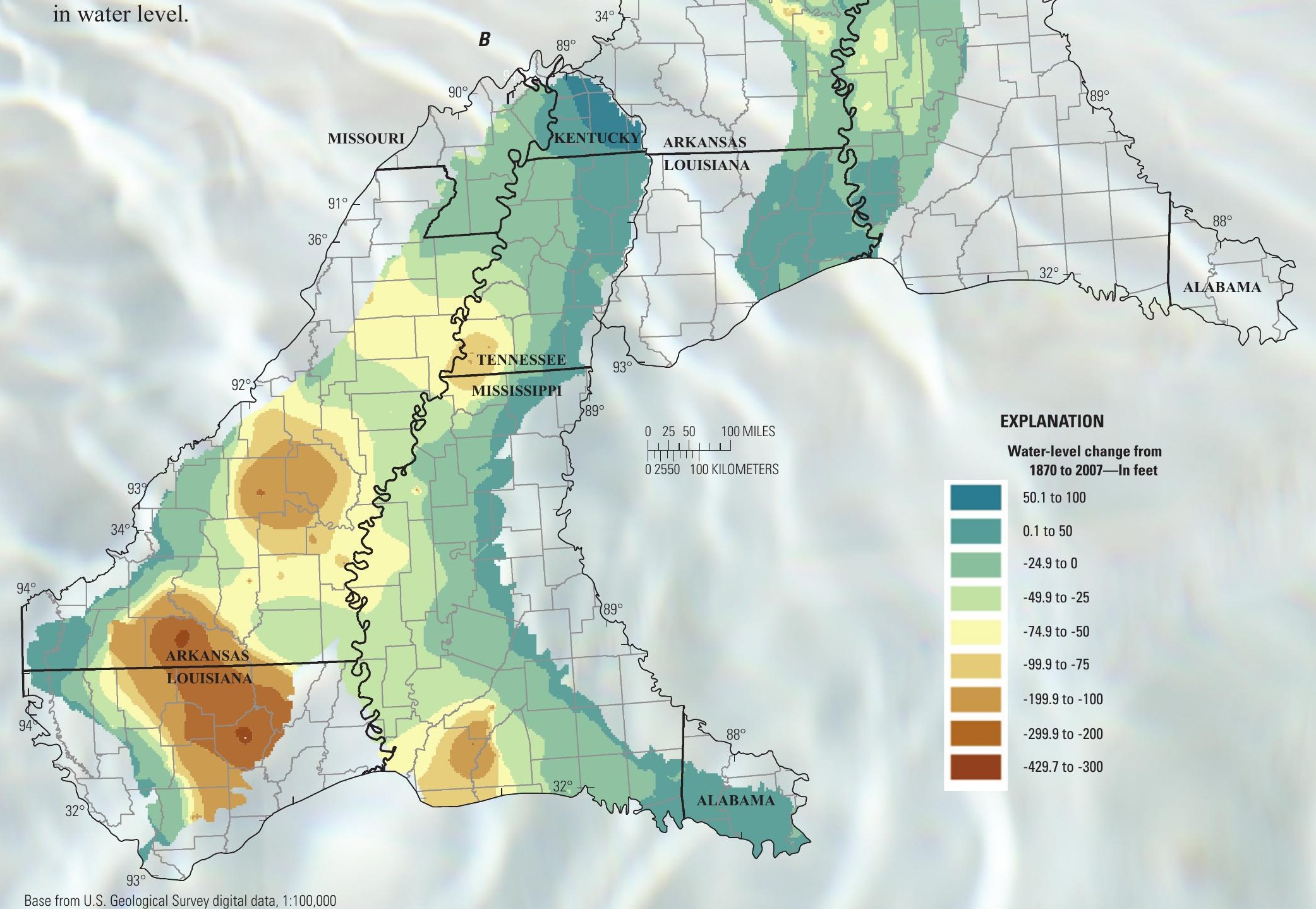

Figure 4. Water-level change from 1870 to 2007 in the $A$, Mississippi River Valley alluvial aquifer and $B$, in the middle Claiborne aquifer. 


\section{How can we determine the future availability of groundwater in the Mississippi embayment?}

As with other areas within the United States, the populace of the Mississippi embayment is concerned with declining water levels and depletion of regionally important aquifers. Pumping from the alluvial aquifer ranked third in the Nation for total withdrawals in 2005. Arkansas ranked first in the Nation for rice and third for cotton production, and Mississippi ranked first for aquaculture and fourth for cotton production in 2007 . These commodities rely on groundwater.

A holistic analysis of groundwater-flow systems is increasingly important. Previous studies included the use of numerical models to simulate the groundwater-flow system on a local scale, such as part of an aquifer in a State. The MERAS examined the larger regional and aquifer-scale system to better understand how all the parts interact to provide information to stakeholders addressing the groundwater-availability issues.

While future availability of groundwater in the Mississippi embayment involves many factors that make a definite answer impossible, the MERAS model tool enables area water managers to view the regional aquifer system in an integrated way and to understand how future changes to the system - driven by human uses or climate variability - may affect future availability. This is an opportunity to forecast system response that would not be possible without this tool. Furthermore, the MERAS model tool allows managers in area States and municipalities to find a balance between water supply and demand for future economic and environmental uses.

\section{What are some of the products and results of the MERAS work?}

The importance of the MERAS work lies not only in the direct results from the study, but from the databases and tools created that water managers can continue to use in the future. Some of these tools, databases, and direct results consist of:

- The MERAS model is a tool, which may be used to evaluate pumping or climate changes, consists of 13 layers over 78,000 square miles representing multiple aquifers and confining units for the period of 1870 to 2007 . A database of over 2,600 geophysical logs was used in the construction of the hydrogeologic framework and is available online at http://pubs.usgs.gov/sir/2008/5192/.

- Cumulative groundwater pumpage from 1870 to 2007 from the alluvial aquifer amounts to over 280 million acre-feet.

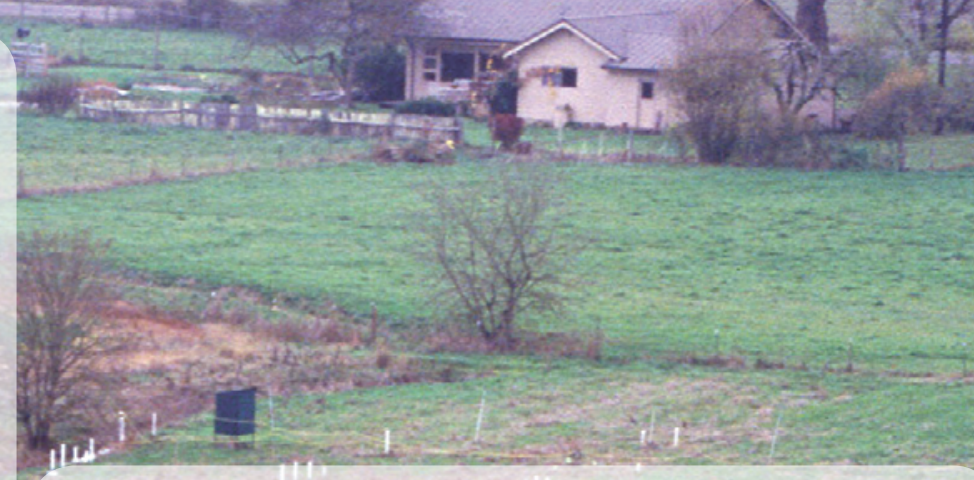

- Cumulative change in storage within all the aquifers simulated in the MERAS model indicates overall depletion of 140 million acre-feet.

\section{Where can I get more MERAS study information?}

To get more information about MERAS, go to http:// ar.water.usgs.gov/meras, which includes downloadable data and publications.

\section{References}

Clark, B.R., Hart, R.M., and Gurdak, J.J., 2011, Groundwater availability of the Mississippi embayment:

U.S. Geological Survey Professional Paper 1785, 62 p. (Available at http://pubs.usgs.gov/pp/1785/.)

Clark, B.R., and Hart, R.M., 2009, The Mississippi Embayment Regional Aquifer Study (MERAS) - Documentation of a groundwater-flow model constructed to assess water availability in the Mississippi embayment: U.S. Geological Survey Scientific Investigations Report 2009-5172, 61 p. (Available at http://pubs.usgs.gov/ sir/2009/5172/.)

Hart, R.M., and Clark, B.R., 2008, Geophysical log database for the Mississippi Embayment Regional Aquifer Study (MERAS): U.S. Geological Survey Scientific Investigations Report 2008-5192, 8 p. (Available at http://pubs.usgs.gov/sir/2008/5192/.)

\section{-Brian R. Clark and David A. Freiwald}

For more information concerning this publication contact:

Director
USGS Arkansas Water Science Center
401 Hardin Road
Little Rock, Arkansas 72211
501-228-3600
Email: dc_ar@usgs.gov

Or visit the Arkansas Water Science Center Web site at: http://ar.water.usgs.gov 